\title{
Prion: the infectious protein in neurodegenerative diseases
}

\author{
M.M. Vita Kurniati, Septelia Inawati Wanandi
}

\begin{abstract}
Abstrak
Prion merupakan suatu partikel infeksius yang menyebabkan beberapa penyakit neurodegeneratif, seperti penyakit CreutzfeldtJakob, penyakit kuru, sindrom Gerstmann-Sträussler-Scheinker dan insomnia familial fatal pada manusia, serta penyakit sapi gila, scrapie, feline spongiform encephalopathy pada hewan. Partikel ini merupakan suatu protein dan tidak mengandung asam nukleat. Protein prion normal $\left(\operatorname{PrP}^{\mathrm{C}}\right)$ dapat berubah menjadi bentuk-samanya yang abnormal $\left(\operatorname{Pr}^{\mathrm{Sc}}\right)$ melalui suatu proses modifikasi pascatranslasi. Perubahan $\operatorname{Pr} P^{\mathrm{C}}$ menjadi $\operatorname{Pr} P^{\mathrm{Sc}}$ tersebut merupakan suatu perubahan konformasi sehingga terjadi perubahan heliks- $\alpha$ menjadi lembar- $\beta$. Pembentukan $P r P{ }^{S c}$ juga memerlukan peran protein $X$, yang belum diketahui. Protein X ini mungkin berperan sebagai suatu chaperone. Dalam dua dekade terakhir ini, banyak karakteristik prion yang telah terungkap, seperti karakteristik fisik, kimiawi, strain, biologi molekuler dan imunologik. Beberapa peneliti juga telah menemukan bentuk topologis protein prion dalam membran retikulum endoplasma serta peran bentuk-bentuk topologis tersebut dalam proses patofisiologis penyakit. Namun demikian, masih banyak pertanyaan mengenai penyakit prion yang belum terjawab. Salah satu aspek prion yang belum terungkap adalah multiplikasi prion. Dari beberapa model multiplikasi prion yang diajukan oleh para peneliti, terdapat satu hal yang selalu diungkapkan yaitu bahwa replikasi prion memerlukan interaksi $\operatorname{PrP}^{\mathrm{C}}$-PrP $P^{\mathrm{Sc}}$. Penelitian mengenai patogenesis penyakit prion juga perlu mendapat perhatian untuk mengembangkan terapi yang efektif untuk penyakit neurodegeneratif ini. Diagnosis penyakit prion ditegakkan berdasarkan temuan klinis, histopatologis dan uji imunokimia dari beberapa protein dalam cairan serebrospinal. Uji imunokimia dari protein dalam cairan serebrospinal ini penting untuk menegakkan diagnosis pramortem dari penyakit prion.
\end{abstract}

\begin{abstract}
Prion particle is an infectious agent causing neurodegenerative diseases in humans and animals, such as Creutzfeldt-Jakob disease, kuru. Gerstmann-Sträussler-Scheinker syndrome, and fatal familial insomnia in humans; mad cow disease, scrapie, and feline spongiform encephalopathy in animals. This particle is devoid of nucleic acid and seems to be composed of protein. The normal prion protein $(\operatorname{Pr} P \mathrm{C})$ is converted into its abnormal isoform $\left(\operatorname{Pr} P^{\mathrm{Sc}}\right)$ posttranslationally. The conversion of $\operatorname{Pr} P^{\mathrm{C}}$ into $\operatorname{Pr} P^{\mathrm{Sc}}$ involves a conformational change whereby the $\alpha$-helical content decreases and the amount of $\beta$-sheet increases. The formation of PrP $P^{S \mathrm{c}}$ requires an unknown protein $X$ which might function as a molecular chaperone. Many prion characteristics have been revealed in these last two decades, such as physical, chemical, strain, molecular biology, and immunological characteristics. Some investigators revealed the topological forms of prion protein in the endoplasmic reticulum membrane and their role in the pathophysiological process of the disease. But still prion diseases continue to raise many unanswerable questions to be investigated. One of the unanswerable questions is prion multiplication. Many prion multiplication models are suggested by investigators; one constant finding is that prion replication requires the interaction of $\operatorname{PrP}{ }^{\mathrm{C}}-\mathrm{PrP}^{\mathrm{Sc}}$. The studies of pathogenesis of prion diseases need much more attention to develop an effective therapy for these neurodegenerative diseases. Diagnosis of prion diseases is based on the clinical and histopathological findings, and immunochemical tests of some proteins in cerebrospinal fluid. Immunochemical tests of proteins in cerebrospinal fluid are important in developing premortem diagnosis of prion diseases.
\end{abstract}

Keywords: scrapie, kuru, Creutzfeldt-Jakob disease, conformational change

During the past two decades, a transmissible pathogen causing a group of human and animal neurodegenerative diseases has been found. This infectious agent is different from both viroids and viruses. Some investigators had indicated that this agent could not be inactivated by procedures modifying or hydrolyzing

Department of Biochemistry, Faculty of Medicine University of Indonesia, Jakarta, Indonesia nucleic acid, such as nuclease digestion, or UV irradiation. ${ }^{1,2}$ Other evidence shows that the agent contains a protein that is required for infectivity, and its infectivity is lost upon inactivation by proteinase $\mathrm{K}$, detergent (sodium dodecylsulphate), guanidinium thiocyanate, or urea (Table 1). ${ }^{2}$ On the basis of these evidence, the term "prion" was introduced to distinguish this infectious pathogen from those responsible for viral illness, i.e. viruses and viroids. ${ }^{\prime}$ Prion has an operational definition, i.e. small proteinaceous infec- 
tious particles which resist inactivation by procedures that modify nucleic acids. The term prion emphasizes that the infectivity of this transmissible pathogen of the neurodegenerative diseases depends on a protein component. ${ }^{1,2}$

Prion diseases are neurodegenerative disorders of humans and animals causing severe neurologic dysfunction and death. Prions cause four transmissible neurodegenerative diseases of humans and six of animals. Human prion diseases, can manifest as infectious, sporadic, and inherited forms, include kuru, Creutzfeldt-Jakob disease (CJD), fatal familial insomnia (FFI), and Gerstmann-Sträussler-Scheinker syndrome (GSS). The animal prion diseases include the following: scrapie of sheep, transmissible mink encephalopathy (TME), chronic wasting disease (CWD) of mule, deer and elk, bovine spongiform encephalopathy (BSE), feline spongiform encephalopathy (FSE), and exotic ungulate encephalopathy.

Table 1. Stabilities of prion and viroids against physical, chemical and enzymatic treatment (modified from Prusiner ${ }^{2}$ )

\begin{tabular}{lcc}
\hline & Viroid & Prion \\
\hline Physical treatment : & & \\
UV irradiation 254 nm & + & - \\
Chemical treatment : & & \\
SDS & - & + \\
Phenol & - & + \\
Urea 3 M & - & + \\
Guanidium thiocyanate 1 M & - & + \\
Psoralen & - & + \\
Enzymatic treatment : & & - \\
RNase A & + & - \\
DNase & + & + \\
Proteinase K & - & + \\
Trypsin & - & \\
\hline
\end{tabular}

$+=$ inactivated; - = no change in infectivity

The normal cellular prion protein $\left(\mathrm{Pr}^{\mathrm{C}}\right)$ has an abnormal isoform, called scrapie prion protein $\left(\mathrm{PrP}^{\mathrm{Sc}}\right)$. The conversion of $\operatorname{Pr} \mathrm{P}^{\mathrm{C}}$ into $\mathrm{Pr} \mathrm{P}^{\mathrm{Sc}}$ is a posttranslationally modified process that involves a change in the conformation without evidence for chemical modification. Both PrP isoforms are encoded by a chromosomal gene. The human PrP gene maps to the short arm of chromosome 20 and is designated PRNP; the mouse $\operatorname{PrP}$ gene maps to chromosome 2 and is designated Prn-p. 1

\section{Characteristic of the cellular prion protein and scrapie prion protein}

The $\operatorname{PrP}^{\mathrm{C}}$ and $\mathrm{PrP}^{\mathrm{Sc}}$ have a molecular weight $\left(\mathrm{M}_{\mathrm{r}}\right)$ of 33 to $35 \mathrm{kD}^{1}{ }^{1}$ Both $\operatorname{PrP}^{C}$ and $\operatorname{PrP}^{\mathrm{Sc}}$ are encoded by a single exon of the chromosomal gene as proteins with the same 254 amino acid sequence. The first 22residues at the $\mathrm{NH} 2$ terminal is cleaved posttranslationally. $^{3,4}$ The PrP protein is glycosylated with $\mathrm{N}$-linked oligosaccharides. ${ }^{4}$ The $\operatorname{PrP}^{\mathrm{C}}$ is a plasma membrane glycoprotein. $\operatorname{PrP}^{C}$ is anchored to the plasma membrane by a glycosyl-phosphatidylinositol (GPI) moiety located at the $\mathrm{COOH}$ terminus of the polypeptide chain. The anchor is added post-translationally in the endoplasmic reticulum, following cleavage of a 23-residue $\mathrm{COOH}$-terminal hydrophobic sequence which serves as a signal for the anchor attachment. $^{3}$

The two PrP isoforms can be distinguished by their different properties. In the proteinase $\mathrm{K}$ digestion, $\mathrm{PrP}^{\mathrm{C}}$ is completely hydrolyzed, whereas only the first 67 amino acids at the $\mathrm{NH} 2$ terminal of $\mathrm{PrP}^{\mathrm{Sc}}$ are hydrolyzed and converted $\operatorname{PrP} 33-35^{\mathrm{Sc}}$ to $\operatorname{PrP} 27-30$ (PrP with a $\mathrm{M}_{\mathrm{r}}$ of 27 to $30 \mathrm{kD}$ ). PrP 27-30 is also called the protease-resistant fragment of $\mathrm{PrP}^{\mathrm{Sc}}$. After detergent solubilization, $\operatorname{PrP}^{C}$ can be solubilized, whilst $\mathrm{PrP}^{\mathrm{Sc}}$ is insoluble, but does not form an ordered array and PrP 27-30 polymerizes into amyloid rods. ${ }^{1,3,4}$ The presence of PrP amyloid rods in some prion diseases has led to assumptions that amyloid formation is essential for the formation of $\operatorname{PrP}^{\mathrm{Sc}}$. However, $\operatorname{PrP}^{\mathrm{Sc}}$ can be formed in the absence of amyloid, and the presence of amyloid plaques is not obligatory for prion diseases. ${ }^{3}$

The physiological function of $\operatorname{PrP}^{\mathrm{C}}$ is unknown, but it appears to be unnecessary since mice in which the $\operatorname{PrP}$ gene has been deleted develop normally and are healthy for more than 9 months. ${ }^{1}$ Recently, some investigators suggested several roles of $\mathrm{PrP}$, such as: postsynaptic PrP might be necessary for GABA-dependent synapses to be fully functional, PrP lacking animals exhibit altered sleep patterns and rhythms of circadian activity. $\operatorname{PrP}$ also contributes to the prion diseases; the $\operatorname{PrP}$ fragment, $\operatorname{PrP} 106-126$, is toxic to cortical and cerebellar cells.

The studies of PrP indicate that there are two distinct strains of transmissible mink encephalopathy prions, designated hyper (HY) and drowsy (DY). These strains can be distinguished by different physicochemical properties of the PrP $\mathrm{P}^{\mathrm{Sc}}$. DY PrP $\mathrm{Pr}^{\mathrm{Sc}}$ seems to be more protease-sensitive than $\mathrm{HY} \operatorname{Pr} \mathrm{P}^{\mathrm{Sc}}$. 
Studies of CJD demonstrate four distinct patterns of protease-resistant $\operatorname{PrP}$ on Western blots after limited proteolysis. Types 1 and 2 are seen in sporadic CJD and also in some iatrogenic CJD. The third type is seen in acquired prion diseases that arise from a peripheral route of exposure to prions, while central nervous system (CNS) exposure typically resembles sporadic CJD. Type 4 is associated with a new variant CJD which arises from dietary exposure to bovine prions. The bands pattern of type 4 is similar to type 3 , but it can be distinguished from all three types of CJD by a characteristic pattern of band intensities. Type 1 is always associated with genotype MM, type 2 with all genotypes (MM, MV or VV). Type 3 is seen in genotype MV or VV, and type 4 in genotype $M M^{6}$

The transmission of prions from one species to another is generally accompanied by a prolonged incubation time relative to transmission to which the host species is the same. ${ }^{1,7}$ This is often referred to as the "species barrier". The species barrier concept is important in assessing the risk for humans of developing CJD after consumption of scrapie-infected lamb or BSE beef. There are three factors that might contribute to the species barrier: (i) the difference in amino acid sequence of $\operatorname{PrP}$ between prion donor and recipient, (ii) strain of prion, (iii) the species specificity of protein $\mathrm{X}$, a factor that binds to $\operatorname{PrP}^{\mathrm{C}}$ and facilitates $\operatorname{Pr} \mathrm{P}^{\mathrm{Sc}}$ formation. ${ }^{7} \operatorname{PrP}^{C}$ is most efficiently converted to $\operatorname{PrP}^{\mathrm{Sc}}$ when the amino acids sequences of $\operatorname{PrP}^{\mathrm{C}}$ and $\mathrm{PrP}^{\mathrm{Sc}}$ are identical. ${ }^{8}$

Studies of $\operatorname{PrP}$ genes responsible for the prolonged incubation time in mice have demonstrated genetic linkage between Prn-p gene and a gene modulating incubation time, $\operatorname{Prn}-\mathrm{i}$. This Prn-i gene maps to mouse chromosome 2. ${ }^{1,4}$ Prn-p and Prn-i are very closely linked and lie adjacent on the chromosome. ${ }^{4}$ The incubation time is also influenced by the $\operatorname{PrP}$ sequence. When prions are passaged into mice with a nonmatching $\operatorname{PrP}$ sequennce, the incubation time is longer than that in mice with a matching PrP sequence. ${ }^{8}$

Another characteristics of this agent are that the agent is not destroyed by boiling in water, and it is not in activated by standard exposure in an autoclave to wet heat at $121{ }^{\circ} \mathrm{C}$ for $15 \mathrm{~min}$. Exposure to $134-138{ }^{\circ} \mathrm{C}$ for $18 \mathrm{~min}$ in porous-load autoclave is currently recommended but may not be adequate in all circumstances. The scrapie agent withstands alcohol and strong disinfectants such as formaldehyde and glutaraldehyde. Formaldehyde may even increase its heat-stability. It may be inactivated by exposure for 1 hour to sodium hypochlorite providing $2 \%$ available chlorine. The infectivity of scrapie affected brain homogenate can pass through small-pore filters. ${ }^{9}$

\section{The formation of the scrapie prion protein}

The prion diseases are due to the conversion of $\operatorname{Pr} \mathrm{P}^{C}$ into $\mathrm{PrP}^{\mathrm{Sc}}$. $\operatorname{PrP}^{\mathrm{Sc}}$ formation is a posttranslational process involving only a conformational change in $\mathrm{PrP}^{\mathrm{C}}{ }^{7}$. In scrapie infected cells, $\mathrm{PrP}^{\mathrm{C}}$ molecules exit to the cell surface then interact with exogenous $\operatorname{PrP}^{\mathrm{Sc}}$. $\mathrm{PrP}^{\mathrm{C}}-\mathrm{Pr} \mathrm{P}^{\mathrm{Sc}}$ re-enter into the cell through a subcellular compartment bounded by cholesterol-rich membranes which might be caveola or endosome. ${ }^{10}$ The formation of new $\operatorname{Pr} \mathrm{P}^{\mathrm{Sc}}$ occurs between the cell surface and internalization in an endosome, non-acidic compartment. Then $\mathrm{PrP}^{\mathrm{C}}$ and $\mathrm{PrP}^{\mathrm{Sc}}$ are transported to lysosomes. Following transport to lysosomes, $\mathrm{PrP}^{\mathrm{C}}$ is degraded, while $\mathrm{PrP}^{\mathrm{Sc}}$ may be shuttled back to the cell surface or induce vacuolar pathology. ${ }^{11} \mathrm{~A}$ critical level of accumulated $\mathrm{PrP}^{\mathrm{Sc}}$ in the lysosomes will disrupt lysosomal membranes, releasing hydrolases into the cell. These enzymes will cause cytoskeletal disruption and spongiform changes. ${ }^{12}$

Conformational studies of prion proteins showed that $\operatorname{PrP}^{\mathrm{C}}$ has a secondary structure which contains about $43 \% \alpha$-helix and only $3 \% \beta$-sheet. ${ }^{10,13}$ Molecular modeling studies predicted four putative $\alpha$-helical regions of $\operatorname{PrP}^{\mathrm{C}}$, denoted helix 1 through helix $4(\mathrm{H} 1$ through $\mathrm{H} 4) .{ }^{7}, 10,13$ Within the four helical regions, 15 residues were identified as potential sites that would mediate helix-helix interaction. ${ }^{13}$ It is suggested that $\mathrm{H} 1$ and $\mathrm{H} 2$ are converted into $\beta$-sheet structures during the formation of $\mathrm{PrP}^{\mathrm{Sc}}$, while $\mathrm{H} 3$ and $\mathrm{H} 4$ remain unchanged (Fig. 1A and $1 \mathrm{~B}){ }^{10}$

Presumably, there is a central domain of $\operatorname{PrP}^{\mathrm{C}}$ (approximately residues 95 to 170 ) that binds to $\mathrm{PrP}^{\mathrm{Sc}}$ during the formation of nascent $\mathrm{Pr}^{\mathrm{Sc}}$. This domain shows higher homology between cattle and humans than between sheep and humans, which raises the possibility that prion transmission from cattle to humans may occur more readily than from sheep to humans. The NH2-terminal domain of $\operatorname{Pr}^{\mathrm{C}}{ }^{\mathrm{C}}$ is thought to form the interface where $\mathrm{PrP}^{\mathrm{Sc}}$ binds.

In contrast to $\operatorname{PrP}^{\mathrm{C}}$, the $\beta$-sheet content of $\operatorname{PrP}^{\mathrm{Sc}}$ is $43 \%$ and $\alpha$-helix content is $30 \%$. Furthermore, $\operatorname{Pr} P$ 27-30 contains 54\% $\beta$-sheet. The formation of $\operatorname{PrP}^{\mathrm{Sc}}$ involves refolding of the $\mathrm{NH} 2$-terminal helices $(\mathrm{H} 1$ and $\mathrm{H} 2)$ into $\beta$-sheets (Fig. 1C). The major conformational change of $\operatorname{Pr} \mathrm{P}^{\mathrm{C}}$ into $\operatorname{Pr} \mathrm{P}^{\mathrm{Sc}}$ has been localized to residues 90 to $112{ }^{7}$ 


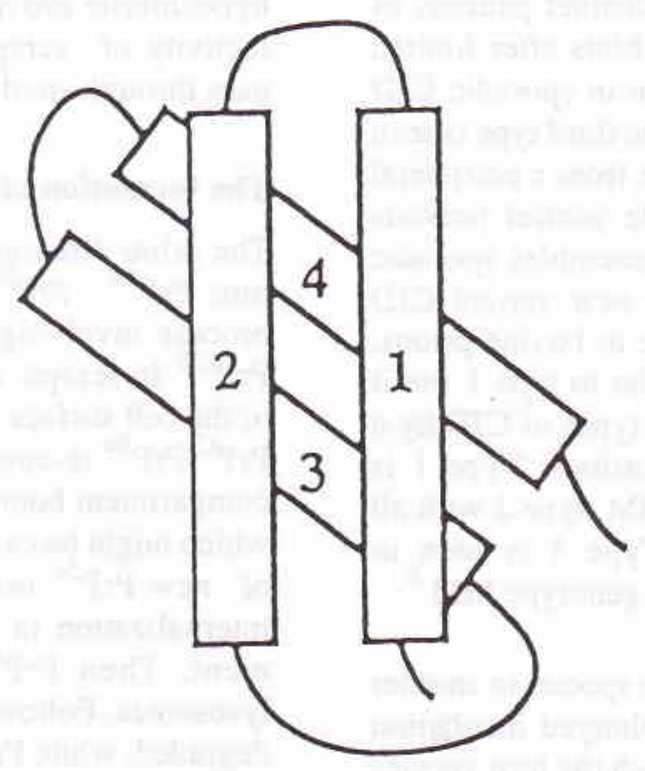

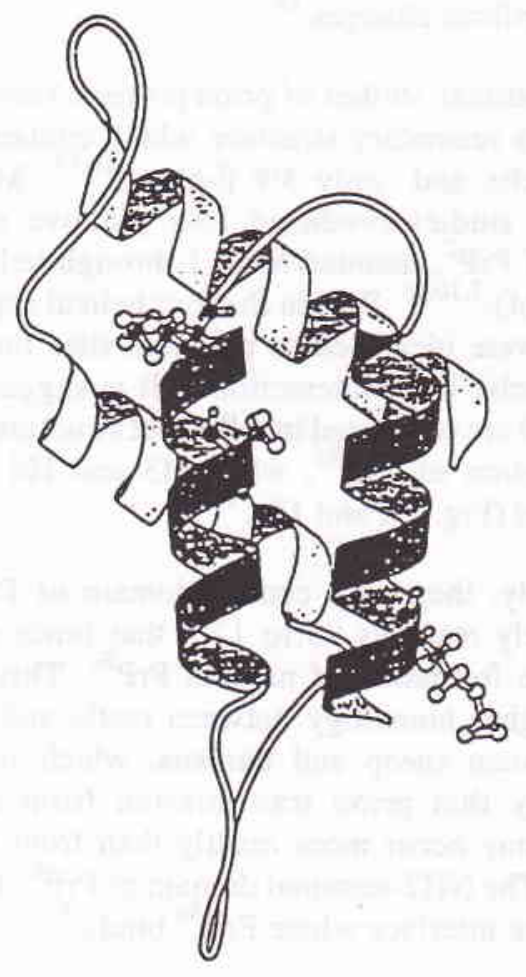

B

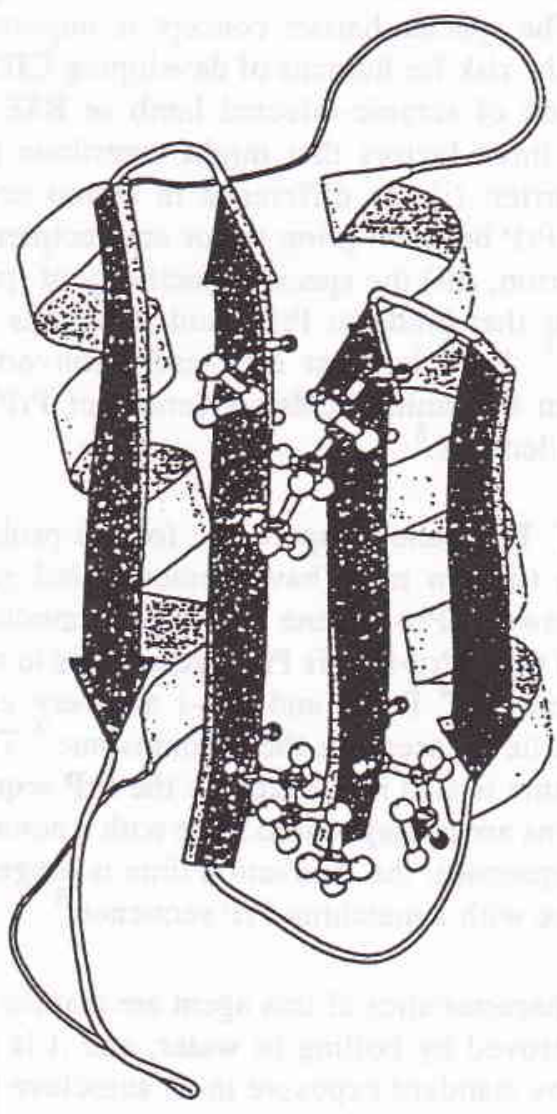

C

Figure 1. (A) Schematic drawing of tertiary structural model of $\operatorname{PrP}^{C} \cdot{ }^{13}$ (B) Plausible model for the tertiary structure of $P r P^{C} .10$ (C) Plausible model for the tertiary structure of $\mathrm{Pr} \mathrm{P}^{\mathrm{Sc}} 10$ 
Mutations of PrP gene can destabilize the conformation of $\mathrm{PrP}^{\mathrm{C}}$ and facilitate its refolding into $\operatorname{Pr} \mathrm{P}^{\mathrm{Sc}}$. Usually PrP gene mutations occur at or near the helixhelix interaction residues. These mutations could disrupt or destabilize the structure of $\operatorname{PrP}^{\mathrm{C}}$ and produce mice or humans which are susceptible to prion disease. Mutation at codon 178 in fatal familial insomnia and familial CJD would eliminate the negative charge that interacts with the positive end of a helix dipole and destabilizes H3. Another mutation at codon 210 that also produces familial CJD would disrupt the $\mathrm{H} 4-\mathrm{H} 1$ interaction and, thus, perturbs the structure of $\operatorname{PrP}^{C}{ }^{13}$

Synthesis of $\operatorname{Pr}{ }^{S c}$ probably also involves another protein which is not known. This protein $\mathrm{X}$, possibly a "chaperone", facilitates the refolding process of $\alpha$ helices in $\mathrm{PrP}^{\mathrm{C}}$ into $\beta$-sheets in $\mathrm{PrP}^{\mathrm{Sc}}$ ?, 10 The $\mathrm{COOH}$ terminal domain of $\mathrm{H} 3$ in $\mathrm{PrP}^{\mathrm{C}}$ appears to contain the site for protein $\mathrm{X}$ binding. ${ }^{7}$ The binding of $\operatorname{Pr}^{\mathrm{C}}$ to protein $\mathrm{X}$ seems to exhibit the highest affinity when these two proteins are from the same species. ${ }^{10}$

\section{Prion protein receptor}

The cell-surface form of the prion protein, $\operatorname{PrP}^{\mathrm{C}}$, is anchored to the plasma membrane by a glycosyl-phosphatidylinositol (GPI) moiety. The internalization of $\mathrm{PrP}^{\mathrm{C}}$ seems to require a protein, a receptor or a prion binding protein. To convert $\operatorname{PrP}^{\mathrm{C}}$ into $\mathrm{PrP}^{\mathrm{Sc}}$, internalization is needed. Martin et al. ${ }^{14}$ noted that there is a neurotoxic region in human prion (residues 106-126) that contains the binding site recognized by a putative cell receptor. Rieger et al. ${ }^{15}$ identified the $37 \mathrm{kD}$ laminin receptor precursor (LRP) as interacting with $\mathrm{PrP}^{\mathrm{C}}$ in yeast, insect and mammalian cells. The $37 \mathrm{kD}$ LRP is located on the cell surface, and it may act as a receptor or co-receptor for the prion protein. ${ }^{15}$

\section{Multiplication of prions}

The mechanism by which prions multiply is not yet clearly established. Several plausible models for the multiplication of prions can be proposed. If the prion contains a small nucleic acid molecule, than this nucleic acid may stimulate the production of $\mathrm{PrP}^{\mathrm{Sc}}$. The $\operatorname{PrP}^{S c}$ would stimulate the production of new copies of the hypothetical small nucleic acid, then this new nucleic acid may combine with $\operatorname{PrP}^{\mathrm{Sc}}$ to form a highly stable infectious complex (Fig. 2A). Alternatively, prions may be devoid of nucleic acid, and $\mathrm{PrP}^{\mathrm{Sc}}$ may stimulate its own synthesis. The $\mathrm{PrP}^{\mathrm{Sc}}$ may combine with the product of Prn-i gene, and this complex would stimulate or catalyze the synthesis of $\mathrm{PrP}^{\mathrm{Sc}}$ (Fig. 2B). It also will be possible that $\operatorname{PrP}^{\mathrm{Sc}}$ alone stimulates the biosynthesis of new $\operatorname{PrP}^{\mathrm{Sc}}$ molecules (Fig. 2C). Another alternative mechanism is a process in which $\mathrm{PrP}^{\mathrm{Sc}}$ (circles) binds to $\operatorname{PrP}^{\mathrm{C}}$ (squares) forming heterodimers that function as replication intermediates in the synthesis of $\operatorname{PrP}^{\mathrm{Sc}}$ (Fig. 2D). ${ }^{1}$

Another plausible model for prion multiplication can be explained by a conformational model. According to this model, the structure of $\operatorname{PrP}^{\mathrm{C}}$ would generate a partially unfolded monomer ( $\left.\operatorname{PrP}^{*}\right)$ that is an intermediate structure in the formation of $\operatorname{Pr} \mathrm{P}^{S c}$. $8,10 \mathrm{PrP} *$ can revert to $\operatorname{PrP}^{C}$, be degraded, or form $\operatorname{PrP}^{\mathrm{Sc}}$. Normally, the concentration of $\mathrm{PrP}^{*}$ would be low, and $\mathrm{PrP}^{\mathrm{Sc}}$ would be formed in insignificant amounts.

In the case of infectious prion diseases, an exogenous prion containing $\mathrm{PrP}^{\mathrm{Sc}}$ would act as a template to promote the conversion of $\operatorname{PrP}^{*}$ into $\operatorname{PrP}^{S c}$, which is likely to be an irreversible process. ${ }^{8}$

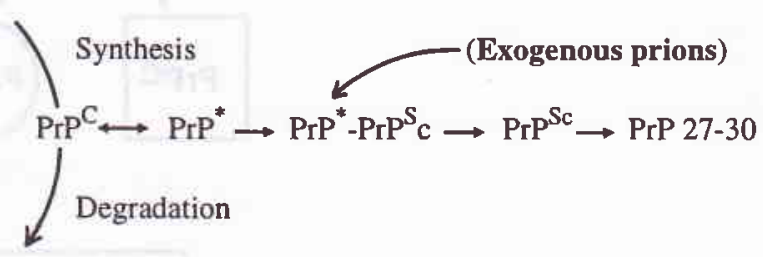

The sporadic prion diseases, in which there are no exogenous prions, may result from the rare occasions in which there is sufficient accumulation of $\operatorname{PrP}^{*}$ to produce $\operatorname{PrP}{ }^{S c}$. The concentration of $\operatorname{PrP}^{\mathrm{Sc}}$ may eventually reach a threshold level upon which a positive feedback loop would stimulate the formation of PrPsc 8

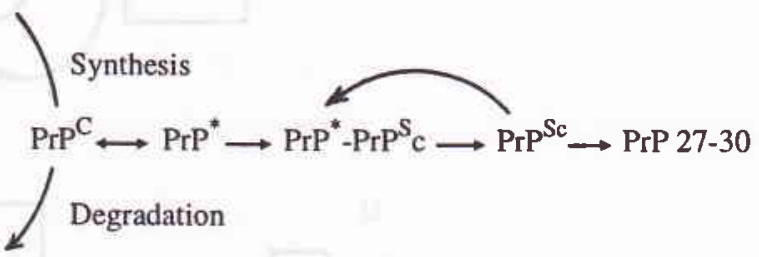

Finally, in the case of inherited prion diseases, $\operatorname{PrP}$ mutations $(\Delta)$ would destabilize $\Delta \operatorname{PrP}^{\mathrm{C}}$ and promote its conversion into $\Delta \operatorname{PrP}^{*}$, which would increase $\Delta \mathrm{PrP}^{\mathrm{Sc}}$ formation. 10

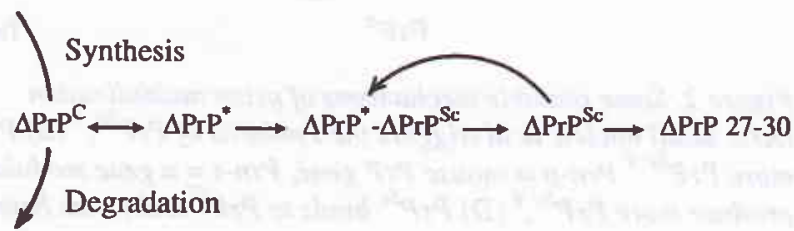


A
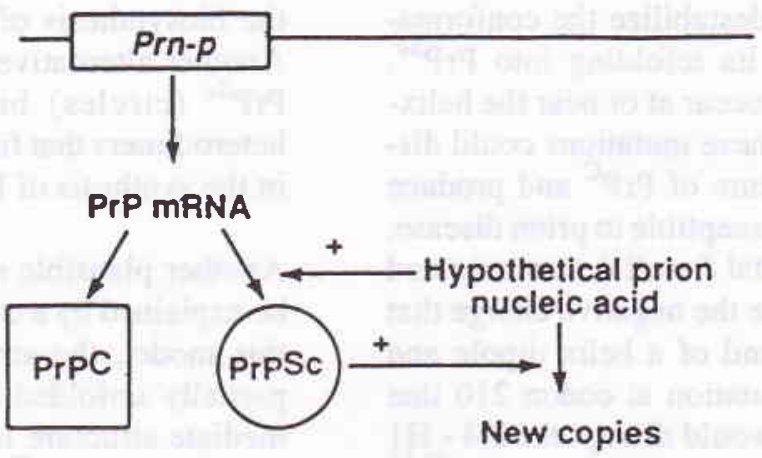

B

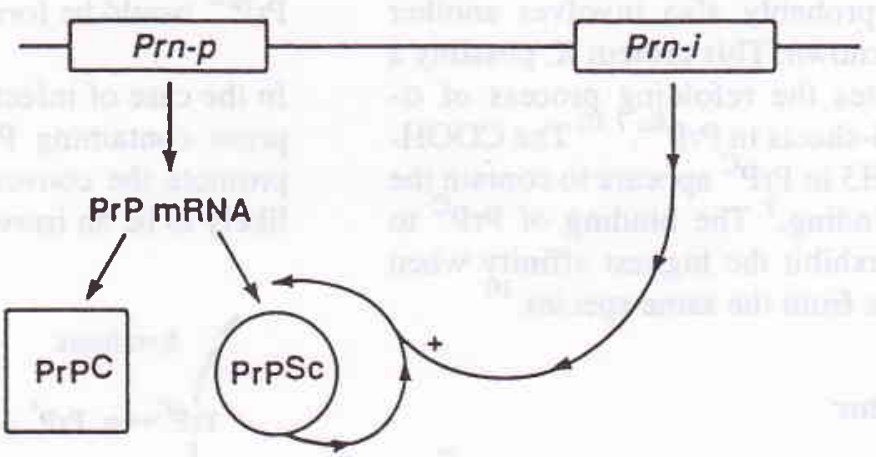

C

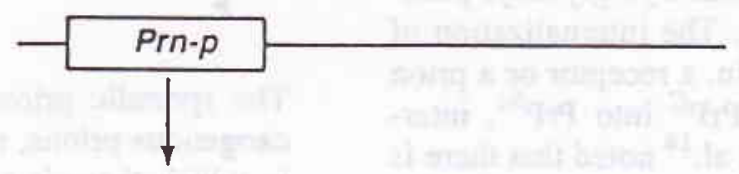

PrP MRNA

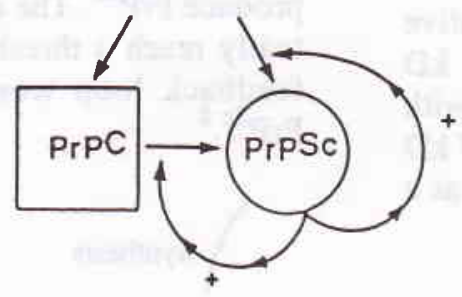

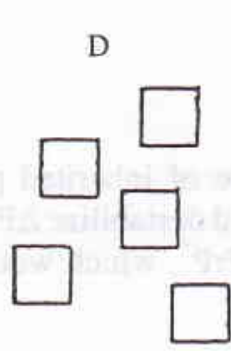

$\operatorname{PrP}^{\circ}$

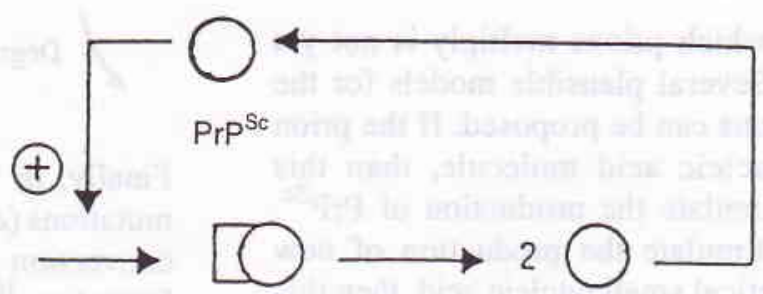

heterodimer

$\operatorname{PrP}^{\mathrm{Sc}}$

Figure 2. Some possible mechanisms of prion multiplication

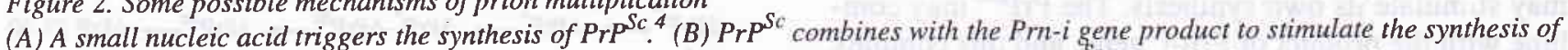
more $\operatorname{PrP}^{S c}{ }^{4}$ Prn-p = mouse PrP gene, Prn-i = a gene modulating incubation time. (C) PrP ${ }^{S c}$ by itself triggers reactions that

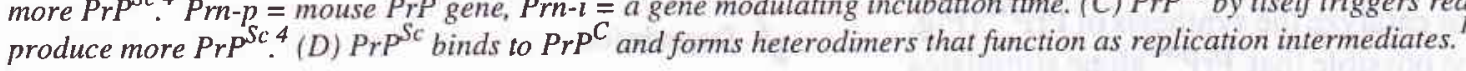


The role of the immune system in the prion disease

It has been noted for years that scrapie infection fails to induce an immune response. This lack of immune response to the infectious scrapie particle can be explained by the discovery that the major component of scrapie $\left(\mathrm{PrP}^{\mathrm{Sc}}\right)$ is a modified form of the host cellular protein $\left(\operatorname{Pr} \mathrm{P}^{\mathrm{C}}\right)$; thus, organisms may not view the scrapie particle as foreign. It is also reasonable to suggest that animals are tolerant to both $\operatorname{PrP}^{C}$ and $\operatorname{PrP}$, because $\mathrm{PrP}^{\mathrm{C}}$ is expressed in most tissues of uninfected animals and is even found on the surface of T lymphocytes, ${ }^{16}$ and $\mathrm{B}$ cells. ${ }^{17}$ The $\mathrm{T}$ and $\mathrm{B}$ cells' tolerance to $\mathrm{Pr} P$ would explain the absence of immune response to scrapie infection. ${ }^{16}$

A scrapie infection from a different species or in the PrP-deficient mice also can not induce an immune response although the scrapie particle would be considered foreign. This absence of immune response is due to the failure of scrapie infection to activate the nonspecific immune mediators that normally signal the invasion of pathogenic microorganisms, such as interferons, tumor necrosis factor, interleukin 1 (IL-1), and IL-6. In the absence of these nonspecific mediators, even foreign proteins do not elicit an immune response. This situation suggests that successful approaches to treating prion diseases cannot depend on activating the immune system. ${ }^{16}$

\section{Topology of prion protein}

Studies of PrP topology at the endoplasmic reticulum (ER) membrane have revealed two distinct forms of PrP: one that is fully translocated into the ER lumen and is termed the secretory form ( ${ }^{\text {sec }} \mathrm{PrP}$ ); and one that spans the membrane (transmembrane) ( ${ }^{\mathrm{tm}} \mathrm{PrP}$ ). Digestion of transmembrane form with proteases added to the outside of the membrane yielded two fragments: one is COOH-terminal derived and glycosylated ( ${ }^{\mathrm{Ctm}-}$ $\operatorname{PrP}$ ), and the other is NH2-terminal derived and unglycosylated ( $\left.{ }^{\mathrm{N} t m} \mathrm{PrP}\right)$. These data indicated that transmembrane PrP chains span the membrane twice, with the NH2- and $\mathrm{COOH}$-termini of the molecule in the ER lumen (Fig. 3). ${ }^{18}$

Hegde et al. examined the possible role of PrP topology in neurodegeneration. Their data showed a marked increase in ${ }^{\mathrm{Ctm}} \mathrm{PrP}$ production at the ER membrane of scrapie infected hamster, with a concomitant decrease in the ${ }^{s e c} \operatorname{PrP}$. The amount of ${ }^{\mathrm{N} t m} \operatorname{PrP}$ remained unchanged. These findings suggest that ${ }^{\mathrm{Ctm}} \mathrm{PrP}$ is involved in the development of spontaneous neurodegenerative disease. ${ }^{18}$
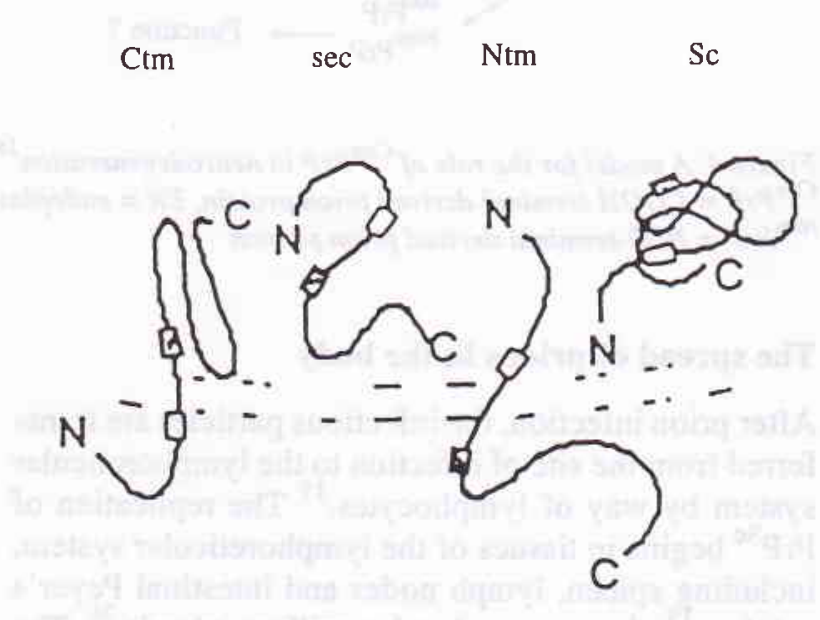

Figure 3. Schematic PrP topology at the endoplasmic reticulum membrane. 18

$C_{t m}=\mathrm{COOH}$-terminal derived, $\mathrm{Sec}=$ secretory form,

$\mathrm{Ntm}=\mathrm{NH2}$-terminal derived, $\mathrm{Sc}=$ scrapie, $N=N$-terminal, $C=C$-terminal.

In normal cells the percentage of ${ }^{\mathrm{Crm}_{\mathrm{Pr}} \mathrm{P}}$ in vivo was consistently lower than that found in vitro. This data suggests that cells normally have mechanisms to prevent the accumulation of this potentially pathogenic protein. Mutation of PrP gene may cause overexpression of ${ }^{C t m} \mathrm{PrP}$, which exceed the cell's ability to eliminate or prevent the synthesis of ${ }^{\mathrm{C} m}{ }^{\mathrm{PrP}} \mathrm{P}$. As a result, ${ }^{C t m} \operatorname{PrP}$ would accumulate, leaves the ER, and trigger the disease. ${ }^{18}$

The pathogenesis of ${ }^{\mathrm{Ctm}} \mathrm{PrP}$-associated neurodegenerative disease includes at least three distinct steps (Fig.4). First, nascent $\operatorname{PrP}$ is synthesized in the ${ }^{\text {sec }}$ PrP, ${ }^{\text {Nim }}$ PrP, or ${ }^{\mathrm{Ctm}}$ PrP form. Second, the ${ }^{\mathrm{Ctn}} \mathrm{PrP}$ form may be rapidly degraded in the ER or, in some cases, may be able to escape degradation to a post-ER compartment. Finally, in the post-ER compartment, ${ }^{\mathrm{Ctm}} \mathrm{PrP}$ is proposed to cause disease. How the ${ }^{\mathrm{Ctm}} \mathrm{PrP}$ can cause the disease, is not yet known. The pathway involving the increase in ${ }^{\mathrm{C} m} \mathrm{PrP}$ may not be the only pathway of neurodegeneration. ${ }^{18}$ 


\section{Fatal familial insomnia}

Fatal familial insomnia (FFI) exhibits insomnia, dysautonomia, ataxia, dysarthria, dysphagia, myoclonus, and signs of pyramidal tract dysfunction. This FFI is caused by a mutation at codon 178 (Asp $\rightarrow$ Asn). However, in contrast to the inherited CJD with a valine residue at codon 129 , a methionine residue was always found at codon 129 of FFI patients. ${ }^{20}$

\section{Bovine spongiform encephalopathy (mad cow disease)}

Bovine spongiform encephalopathy (BSE) was first recognized in Britain in November 1986 in cattle. The cows initially became apprehensive, hyperesthetic, and uncoordinated. Then they became hard to handle, and in some cases they progressed to frenzy, which led to the name "mad cow disease". 20 The mean incubation period is four to five years. 7,20

The BSE agent can be transmitted to another species, such as calves, sheep, goats, and mice, by the oral route, in some cases by very high-challenge doses only. Transmission orally to sheep and goats was possible using $0.5 \mathrm{~g}$ infected bovine brain; and $1 \mathrm{~g}$ of brain was effective in cows. ${ }^{9}$ In humans, there are three possible routes of infection. First, by implantation or injection of bovine-derived materials or preparations associated with bovine products, including "catgut" sutures. Second, workers in animal feed preparation might have been at risk of inhaling infected dust or acquiring the agent conjunctivally. Infection by ingestion is the third possible route. High-titre infectivity challenges seem to be associated with bovine brain, retina, and spinal cord. Medium infectivity is associated with lymphoreticular tissues. Other tissues, including skeletal muscle (meat), milk, and blood, had no detectable infectivity. ${ }^{21}$

The bovine prions in humans can cause some cases which differ in several ways from other cases of CJD. These cases are being called variant Creutzfeldt-Jakob disease (vCJD) or new variant Creutzfeldt-Jakob disease (nvCJD). The patients are young (the age range is between 16 and 41), and presenting behavioral changes, ataxia, and peripheral sensory disturbances, while progressive dementia developed later. The PrP genes in all cases analyzed showed no mutation and are homozygous for methionine at codon 129 (the same as in cattle). ${ }^{20}$

\section{Alzheimer's disease}

The hallmark of Alzheimer's disease is the accumulation of several abnormal proteins in the brain, such as amyloid $\beta$ protein, $\beta$ protein precursor, $A$ po $E$, and $\operatorname{PrP}$. These proteins are present in the muscle fibers. The muscle fibers also demonstrated increased $\operatorname{PrP}^{\mathrm{C}}$ mRNA while the abnormal brains of patients with prion diseases did not have increased $\operatorname{PrP}^{\mathrm{C}}$ mRNA. ${ }^{22}$

\section{Diagnosis of prion diseases}

The diagnosis of prion diseases is based on clinical and neuropathological findings. The typical neuropathological findings of these diseases are spongiform change, astrocytosis, and neuronal loss. Of these the most specific is the spongiform change, which consists of diffuse or focally clustered, small, round vacuoles that may become confluent. In some cases, there are amyloid plaques composed of extracellular accumulation of $\operatorname{PrP} .^{23}$ The definitive diagnosis can only be made by histopathological examination of brain biopsy specimen. ${ }^{23,24}$ Brain biopsy, however, places patients and health personnel at risk and may miss the site of disease. $^{23}$

Most cerebrospinal fluid proteins in CJD patients showed two 30-kD proteins detected by two-dimensional electrophoresis and designated as protein 130 and 131 . These two proteins are $14-3-3$ proteins. The 14-3-3 protein was abundant in an extract of normal human brain, but it was not found in normal serum and in serum from CJD patients. In humans and other mammals, 14-3-3 is a normal neuronal protein consisting several isoforms, and it plays a part in conformational stabilization of other proteins. The presence of 14-3-3 in cerebrospinal fluid may be due to massive neuronal disruption and the leakage of brain proteins into cerebrospinal fluid. The quantity of 14-3-3 present in cerebrospinal fluid may be propotional to the rate and the amount of neuronal destruction. ${ }^{23}$

The 14-3-3 proteins can be detected by an immunoassay method. This 14-3-3 protein can also be found in cerebrospinal fluid from patients with herpes simplex encephalitis or recent infarctions. Therefore, it should be emphasized that the need to use the 14-3-3 marker as a test is only useful in an appropriate clinical setting. For a patient with dementia, the detection of 14-3-3 in cerebrospinal fluid strongly supports a diagnosis of CJD. $^{23}$

Some other studies in small numbers of patients have suggested that there is another protein in cerebrospinal fluid which is increased in the early phase and returns to normal in the late stages of the CJD. This protein is 
neuron-specific enolase (NSE). This enzyme is a 78$\mathrm{kD}$ protein, localized in neurons and neuroendocrine cells, synthesized virtually completely within the central nervous system. Raised NSE levels in cerebrospinal fluid have also been reported in other neurological disorders, such as brain trauma, brain tumors, subarachnoid haemorrhage, and acute stroke. The cut-off value of cerebrospinal fluid NSE is 35 $\mathrm{ng} / \mathrm{ml}$. This value should only be considered as highly suggestive of CJD when other diseases, such as ischaemic stroke or brain tumours have been excluded. NSE in cerebrospinal fluid appears to be a valuable biochemical marker in cases of advanced dementia when the clinical diagnosis of CJD cannot be corroborated by electro-encephalography. ${ }^{24}$

\section{Therapeutics for prion diseases}

The most attractive therapeutic target is interfering with the conversion of $\operatorname{PrP}^{\mathrm{C}}$ into $\operatorname{Pr} \mathrm{P}^{\mathrm{Sc}}$. There are several therapeutic strategies that can be suggested, i.e. stabilizing the structure of $\operatorname{PrP}^{\mathrm{C}}$ by binding it to a drug; modifying the action of protein $\mathrm{X}$, which might function as a molecular chaperone. The $\mathrm{PrP}^{\mathrm{Sc}}$ formation seems to be limited to caveola-like domains so the drugs do not need to penetrate the cytosol of the cells, but they must be able to enter the CNS. Drugs that destabilize the structure of $\operatorname{PrP}^{\mathrm{Sc}}$ might also prove useful. ${ }^{7}$

The transformation of $\operatorname{Pr} \mathrm{P}^{\mathrm{C}}$ into $\mathrm{PrP}^{\mathrm{Sc}}$ requires an interaction of $\operatorname{PrP}^{\mathrm{C}}-\mathrm{PrP}^{\mathrm{Sc}}$. There are some sulfated polyanion compounds, such as pentosan sulfate, dextran sulfate, heparin, amyloid binding dye Congo red, that can irreversibly inhibit $\mathrm{PrP}^{\mathrm{Sc}}$ formation and prion synthesis. ${ }^{11,25}$ Coughey et al., citated by $\mathrm{Be}$ ssen, ${ }^{11}$ observed that $\operatorname{PrP}{ }^{C}$ can bind directly to sulfated glycans, Congo red, and endogenous glycosaminoglycans, suggesting that sulfated polyanions may competitively inhibit $\operatorname{PrP}^{\mathrm{C}}-\mathrm{PrP}^{\mathrm{Sc}}$ interaction. Shyng et al. ${ }^{25}$ found that these compounds could decrease the amount of $\operatorname{PrP}^{C}$ on the surface of neuroblastoma cells, by enhancing the rate of $\operatorname{PrP}^{\mathrm{C}}$ endocytosis. The sulfated glycans may also redistribute a portion of PrP molecules to an endocytic compartment that is unfavorable for the conversion process. ${ }^{25}$

Understanding how $\mathrm{PrP}^{\mathrm{C}}$ unfolds and refolds into $\mathrm{PrP}^{\mathrm{Sc}}$ may open new approach to deciphering the causes of and developing effective therapies for the more common neurodegenerative diseases, including Alzheimer's disease and Parkinson's disease.

\section{CONCLUSION}

Prion is an infectious protein that cause neurodegenerative diseases in humans and animals. The prion protein $(\operatorname{PrP})$ consists of two isoforms i.e. $\operatorname{Pr} \mathrm{P}^{\mathrm{C}}$, the normal isoform, and $\operatorname{PrP}^{\mathrm{Sc}}$, the abnormal one. The conversion of $\operatorname{PrP}^{C}$ into $\operatorname{PrP}^{\mathrm{Sc}}$ is a posttranslational process that involves a conformational modification. How $\operatorname{PrP}^{C}$ can be converted into $\operatorname{PrP}^{S c}$ remains to be established although several investigators have suggested some prion multiplication models. Understanding the prion propagation needs much more attention because it may contribute to the development of an effective therapy for these neurodegenerative diseases.

The development of premortem diagnostic test of prions is needed, since a definitive diagnosis of prion diseases by histopathological examination of a brain biopsy specimen is accompanied by high risks. There are biochemical markers, such as neuron-specific enolase and 14-3-3 protein in cerebrospinal fluid, which can provide an objective evidence for the diagnosis of prion diseases, especially the CreutzfeldtJakob disease. These markers can be detected by an immunochemical examination. However, these diagnostic tests should only be considered as a marker in appropriate clinical findings or when other diseases have been excluded.

The understanding of prion diseases might open a new and emerging area of investigation in molecular biology, cell biology, genetics, and protein chemistry.

\section{REFERENCES}

1. Prusiner SB. Genetic and infectious prion disease. Arch Neurol 1993;50:1129-53.

2. Prusiner SB. Novel proteinaceous infectious particles cause scrapie. Science 1982;216:136-44.

3. Baldwin MA, Cohen FE, Prusiner SB. Prion protein isoforms, a convergence of biological and structural investigation. J Biol Chem 1995;270:19197-200.

4. Prusiner SB. Prions and neurodegenerative disease. N Engl J Med 1987;317:1571-81.

5. Estibiero JP. Multiple roles for PrP in the prion diseases. Trends Neurosci 1996;19:257-8.

6. Collinge J, Sidle KCL, Meads J, Ironside J, Hill AF. Molecular analysis of prion strain variation and the aetiology of 'new variant' CJD. Nature 1996;383:685-90.

7. Prusiner SB. Prion diseases and the BSE crisis. Science 1997;278:245-51.

8. Cohen FE, Pan KM, Huang Z, Baldwin M, Fletterick RJ, Prusiner SB. Structural clues to prion replication. Science 1994;264:530-1. 
9. Collee JG, Bradley R. BSE: a decade on-part I. Lancet 1997;349:636-41.

10. Prusiner SB. Molecular biology and pathogenesis of prion diseases. Trends Biochem Sci 1996;21:482-7.

11. Bessen RA. Neurodegenerative prion disease. Science \& Medicine 1996; 3:12-21.

12. Mayer RJ, Landon M, Laszlo L, Lennox G, Lowe J. Protein processing in lysosomes: the new therapeutic target in neurodegenerative disease. Lancet 1992;340:156-9.

13. Huang Z, Gabriel JM, Baldwin MA, Fletterick RJ, Prusiner SB, Cohen FE. Proposed three-dimensional structure for the cellular prion protein. Proc Natl Acad Sci USA 1994; 91:7139-43.

14. Martins VR, Graner E, Garcia-Abreu J, de Souza SJ, Mercadante AF, Viega SS, et al. Complementary hydropathy identifies a cellular prion protein receptor. Nature Med 1997;3:1376-82.

15. Rieger R, Edenhofer F, Lasmezas CI, Weiss. The human $37-\mathrm{kDa}$ laminin receptor precursor interacts with the prion protein in eukaryotic cells. Nature Med 1997;3:1383-8.

16. Berg LJ. Insight into the role of the immune system in the prion diseases. Proc Natl Acad Sci USA 1994;91:429-32.

17. Vogel G. B cells may propgate prions. Science 1997;278: 2050.

18. Hegde RS, Mastrianni JA, Scott MR, DeFeaa KA, Tremblay $P$, Torchia $\mathbf{M}$, et al. A transmembrane form of the prion protein in neurodegenerative disease. Science 1998; 279:827-34.

19. Epstein FH. Transmissible spongiform encephalopathies. $\mathrm{N}$ Engl J Med 1997;337:1821-8.

20. Aguzzi A. Neuro-immune connection in spread of prions in the body? Lancet 1997;349:742-3.

21. Collee JG, Bradley R. BSE: a decade on-part 2. Lancet 1997;349:715-21.

22. Sarkozi E, Askansas V, Engel WK. Abnormal accumulation of prion protein mRNA in muscle fibers of patients with sporadic inclusion-body myositis and hereditary inclusionbody myopathy. Am J Pathol 1994;145:1280-4.

23. Hsich G, Kenney K, Gibbs CJ, Lee KH, Harrington MG. The 14-3-3 brain protein in cerebrospinal fluid as a marker for transmissible spongiform encephalopathies. N Engl J Med 1996;335:924-30.

24. Zerr I, Bodemer M, Racker S, Grosche S, Poser S, Kretzschmar HA, e al. Cerebrospinal fluid concentration of neuron-specific enolase in diagnosis of Creutzfeldt-Jakob disease. Lancet 1995;345:1609-10.

25. Shyng S-L, Lehmann S, Moulder KL, Harris DA. Sulfated glycans stimulate endocytosis of the cellular isoform of the prion protein, PrPC , in cultured cells. J Biol Chem 1995; 270:30221-9.
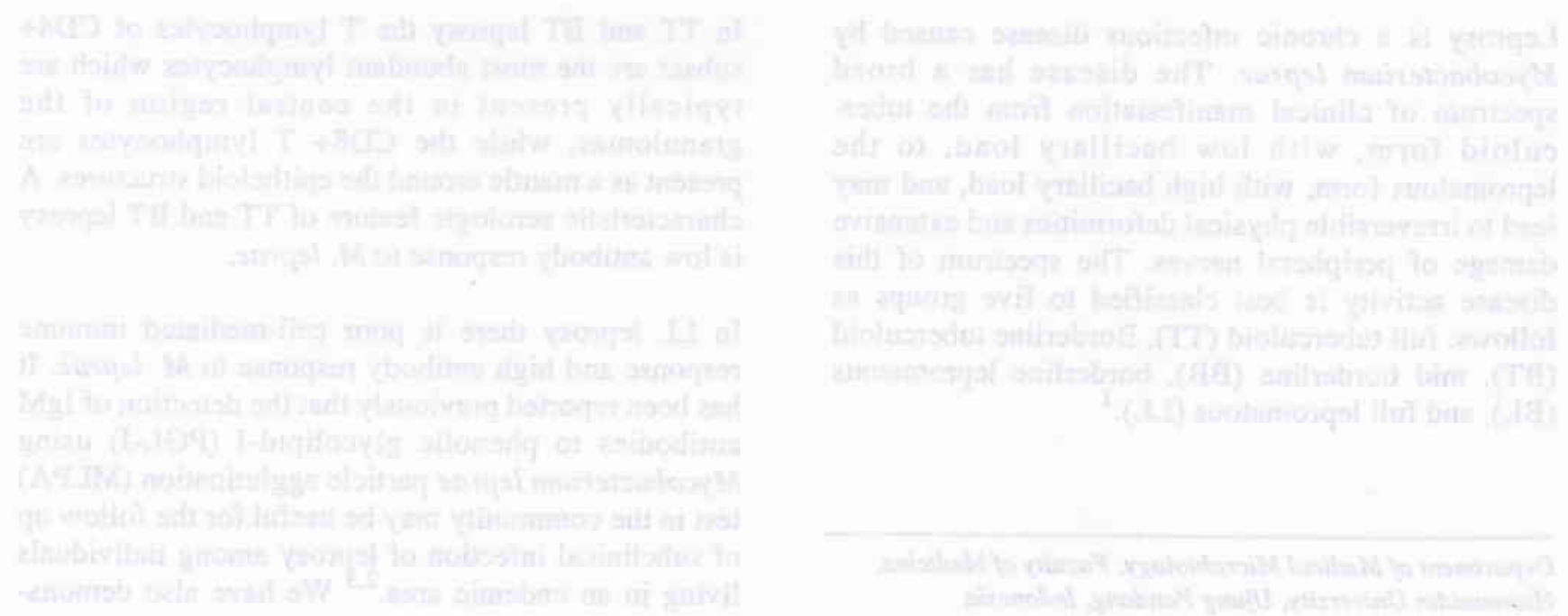